\title{
SOME COMMON ERRORS IN THE NOMENCLATURE OF THE DIPTEROUS WING.
}

\author{
BY s. W. WILliston, CHICAgo, ILL.
}

There are in common use two systems of nomenclature for the dipterous venation at the present time. A third, that proposed by Comstock and Needham, based upon comparative studies, has, so far, not received much approbation among students of the order.

The first and most commonly used of these systems is that given in detail by Loew in the first volume of the Monographs of North American Diptera; the second that adopted by Schiner in his later writings, and, since his time, by Wulp and Verrall especially, as also several other recent writers. Neither of these was the creation of the writers. That given by Loew was merely a codification of the usages of many of the early writers, especially Meigen and Wiedemann, with some additions and modifications proposed by himself. Schiner's system, likewise, was a rehabilitation, with modifications and additions, of the usages of various writers, notably the English, with some terms of the earlier continental entomologists. Loew's terminology was based chiefly upon the muscid venation, which he seemed to look upon as the more typical and primitive; he never attempted to apply his terminology to the nemocerous venation; in fact Loew never took enthusiastically to this division of the diptera. Schiner's system also was more especially applied to the brachycerous and muscid types, though he did attempt to homologize it with the nemocerous venation.

The application of neither system to the Nemocera has been altogether happy. Osten Sacken, when he came to use the Loewian nomenclature in the Tipulidae, was perplexed and led astray by some evident incongruities on Schiner's part, and his example has done more than that of any one else to perpetuate some very palpable errors, which, it seems to me, for the sake of consistency should be corrected - if either of these systems is to be used. Comstock and Needham did better, and their homologies are, for the most part, correct, I believe, though I am far from being assured that they have, in all cases, reached the correct conclusions, or that future researches will not modify the interpretations they have accepted for some of the diptera:

Schiner was the first to reach the conclusion that the 'fourth' longitudinal vein of the wing is the one which may be three-branched; and that the fifth is two-branched 
only. The hind branch of the fifth is the one which Loew called the 'posterior basal cross-vein', but in this Loew was very clearly wrong; this hind branch is not a cross-vein in any sense of the word, and few writers have made use of the term since his time. The vein closing the anal cell in the higher diptera should be known as the 'posterior branch of the fifth vein.' The anterior branch of this vein is the one bounding the fitfh posterior cell, when present, in front, and is always present as a discrete vein in those wings having a discal cell in the vein separating the last posterior cell from the second basal cell. The two branches of this vein are conspicuously evident of course in many of the Nemocera without discal cell. Comstock, agreeing with Schiner, believes that the fourth vein (Vein V) is primitively three-branched, the proximal branch enclosing the discal cell, and, in nearly all cases he assumes that when but a single branch of the fourth vein is present it is the proximal one; a belief with which I do not at all agree. It is a singular fact that no dipteron, (unless it be Lonchoptera) presents a simple three-branched fourth vein unconnected with the fifth, and I am myself inclined to the belief that it is the fifth vein which is normally three-branched and not the fourth; and that the discal cell, when present, is not due to the proximal branching, but rather to the presence of a true cross-vein separating the second basal from the discal cell. I of course have not had the opportunity to study the venation of other orders of insects as had Comstock and Needham, but so far as my studies go, I find no conclusive evidence in them. If the fourth vein is three branched and discal cell present, the vein separating the discal from the second basal is of course the first section of the proximal branch of the fourth vein; if the fifth vein is really the one that is three-branched, then this vein, at the outer end of the second basal, is always a true cross-vein, which it always is in the Comstock system when the discal cell is absent. Schiner it was who, very strangely for so acute an observer, gave to the short vein at the outer end of the second basal cell in the nemocera the name of posterior or great cross-vein, and Osten Sacken, perhaps led astray by his authority at a time when he had not given much thought to the brachycerous diptera, applied to the first section of the anterior branch of the fifth the name of 'great cross-vein' in the Tipulidae. The name 'posterior' or 'great' cross-vein is applied to the cross-vein closing the discal cell outwardly in all the muscid flies. Now it is very evident that the absence of a discal cell, in the mosquitoes for instance, is not due to the coalescence of the discal and second basal cells, but to the absence of the 'posterior cross-vein' of the muscid and brachycerous flies, and the application of this name to the vein at the inner end of the discal cell is very clearly incongruous. My attention to this incongruity was first fixed by the common usage among students of the Culicidae in calling the vein at the outer end of the second 
basal cell the 'posterior cross-vein,' when it is very evidently homologous with the inner vein only, the 'anterior basal cross-vein' of Loew, and that is the name that should be given to it, if we are to use these systems of nomenclature. A moment's consideration will convince the observer that the real posterior cross-vein of other flies is present only in the Tipulidae and Rhyphidae among nemocerous flies.

Again, in all the brachycerous flies that have the third vein furcate, the cells situated between the second vein and the posterior branch of the third are generally

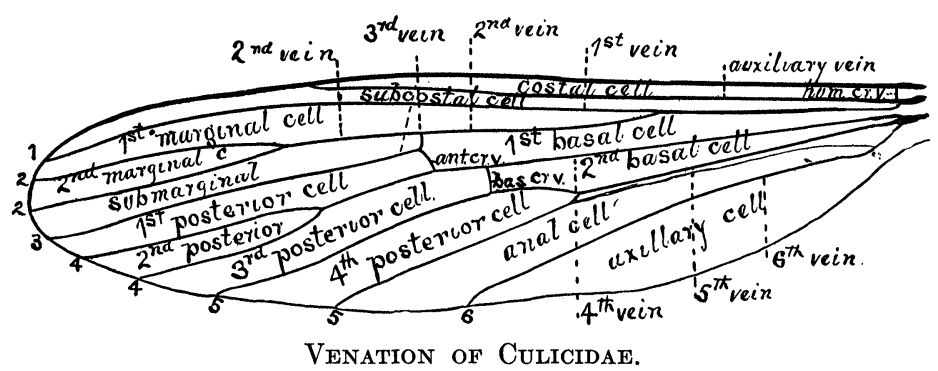

known as submarginal cells, either the 'inner' and 'outer' or first and second, and of course, as in Hyperalonia, the third and fourth sometimes; while the cell between the first and second vein is known as the marginal in the Loewian nomenclature. In the Nemocera again, misled by Osten Sacken's perplexities, the invariable usage is to call the cell formed by the furcation of the second vein the first submarginal. In the exceedingly rare instances (Protoplasta, etc.) in which the third vein is supposed to be furcate in the Tipulidae Osten Sacken gave the name of supernumerary first posterior cell to the second submarginal. The culicidologists speak of the 'first submarginal cell' as being longer or shorter than the second basal; what of course is meant is the 'second marginal cell.'

It is rather a curious fact, for which I can offer no explanation, that the second vein is never furcate among brachycerous flies, while on the other hand the third vein is, I believe, never furcate among nemocerous flies, with the possible exception of Protoplasta and its allies and Psychoda and Pericoma. We find, it is true, an apparent anterior branch of the third vein in many Mycetophilidae, Bibionidae, etc. But, I believe that in every such case this so-called anterior branch is in reality the second vein, which is always otherwise wanting in nemocerous fies having a so-called branch to the third vein. Comstock's homologies are here also more correct than is the common usage. A good example of this shortened second vein will be found in Paltostoma among the Blepharoceridae, and indications also may be found 
among many of the Stratiomyidae, where the second vein confessedly has assumed the position of a branch of the third.

It is perhaps rather a bold opinion, but $\mathrm{I}$ am, nevertheless, inclined to it, that the Phoridae are really members of the Nemocera. The venation of the family is quite identical with that of Aspistes of the Bibionidae, for instance, and is easily explainable on this assumption, but utterly impossible from any other. The fact that the Phoridae have two-jointed palpi, while all the Cyclorrhapha have but a single joint, eliminates them I believe absolutely from membership in that group. The only diptera, aside from certain Nemocera, having two-jointed palpi, so far as my observation and reading go, are the Leptidae, Stratiomyidae, Tabanidae, Pantophthalmidae, Bombyliidae, some Asilidae, Apiocera and the Phoridae. I am not sure about the Empididae. The phorid antennae do not seem to me to offer insuperable objections to the location of the family among the Nemocera. So far as I am aware the first antennal joint in these flies is supposed to be absolutely wanting, the second much reduced in size. Assuming that the so-called third joint is in reality the second joint, it does not require much imagination to conceive that the, at least three-jointed, arista is in reality the whole flagellum of the Nemocera. And we have the Orphnephilidae to help us out in this assumption, where practically the only difference is that of additional aristal joints. Schiner seems to have had the same idea in his association of the Phoridae next to the Bibionidae in his Fauna Austriaca. On the other hand it is a well-known fact that the most primitive antennae of all diptera, so far as the number of distinct joints is concerned, with a few exceptions only among the Cecidomyidae, are found in the Brachycera, not the Nemocera! I may add by way of postscript, that Theobald's interpretation of the Culicid venation in his monograph is incorrect, and betrays a limited knowledge of the venation of allied diptera. 

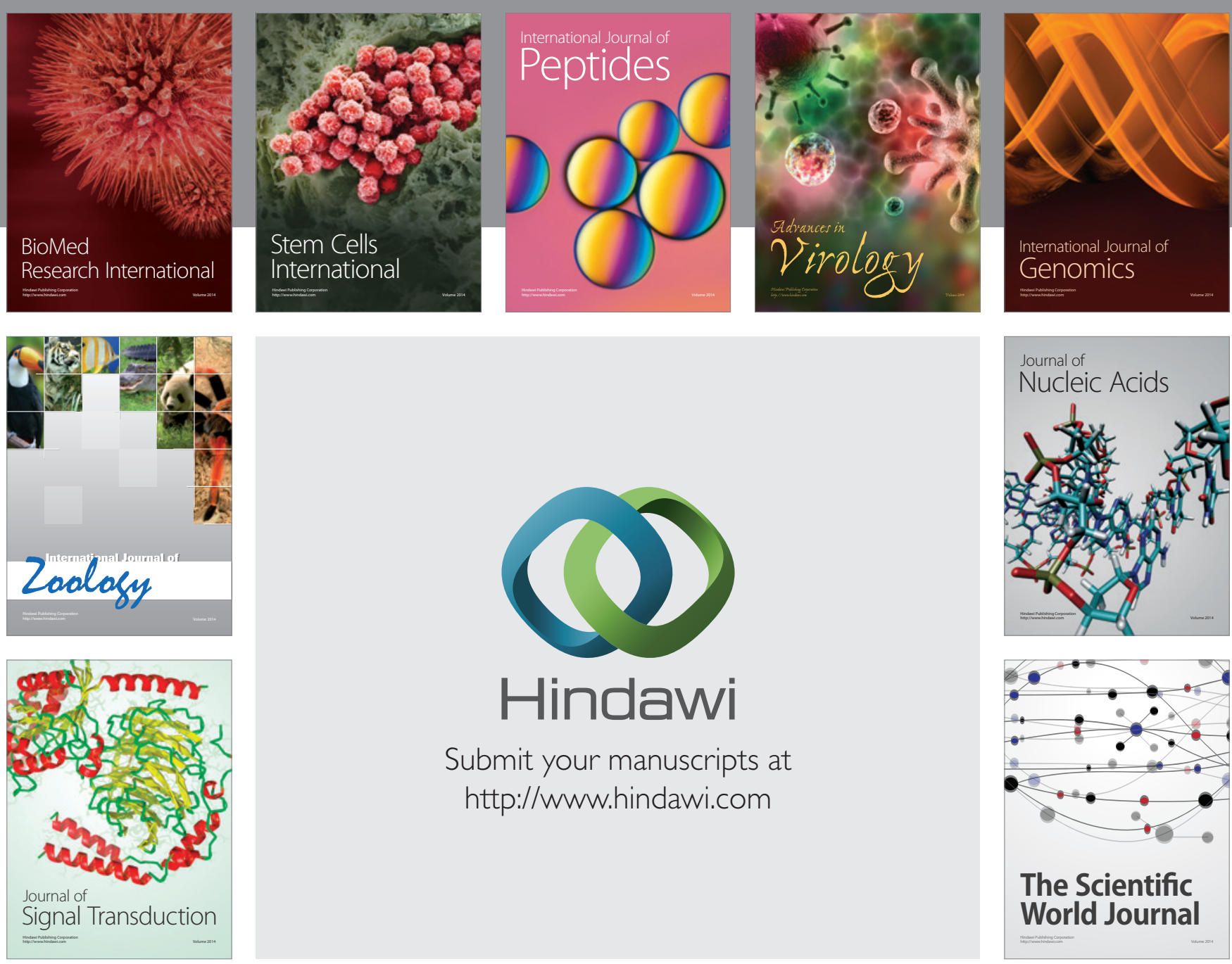

Submit your manuscripts at

http://www.hindawi.com
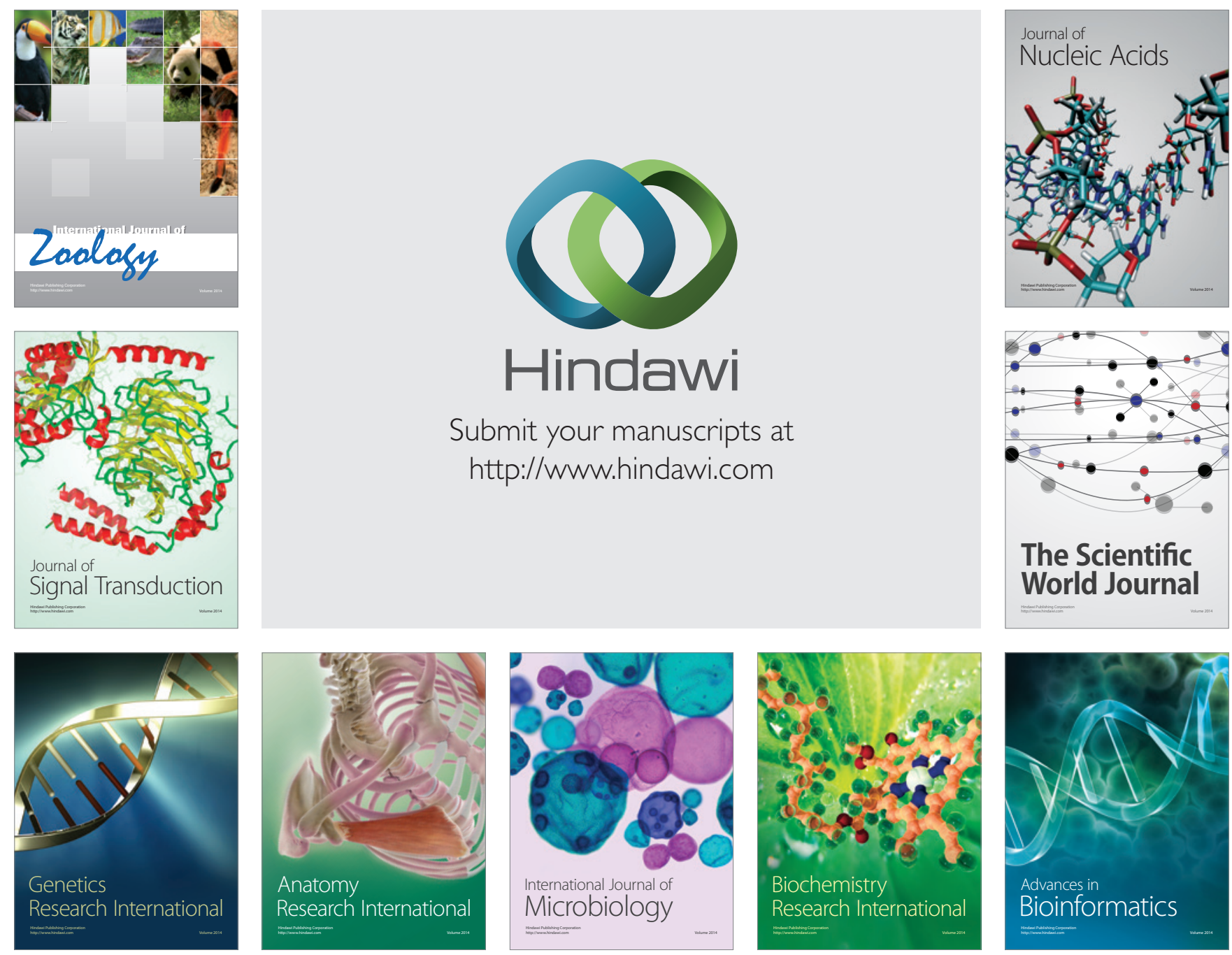

The Scientific World Journal
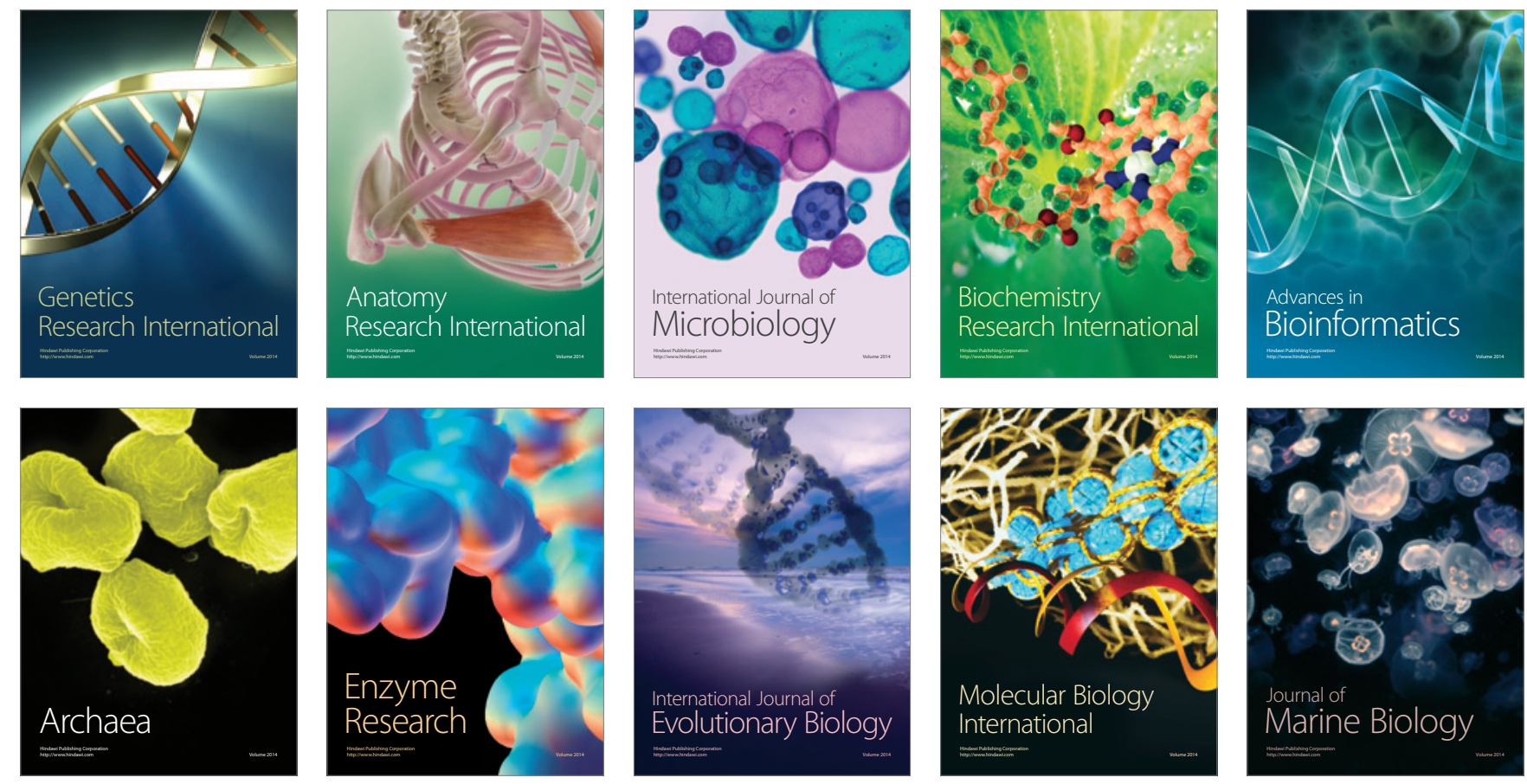